\title{
EFFECT OF SILICON SURFACE TREATMENT ON THE ELECTRICAL AND PHOTOELECTRIC PROPERTIES OF NANOSTRUCTURED $\mathrm{MoO}_{\mathrm{x}} / \mathbf{n}-\mathrm{Si}$ HETEROJUNCTIONS
}

\author{
Mykhailo Solovan*, (D)Taras Kovaliuk, (D)Pavlo Maryanchuk \\ Yuriy Fedkovych Chernivtsi National University, \\ st. Kotsyubyns'kogo 2, 58012, Chernivtsi, Ukraine \\ *E-mail:m.solovan@chnu.edu.ua \\ Received March 13, 2019; revised April 24, 2019; accepted May 7, 2019
}

\begin{abstract}
The paper presents the results of studies of the effect of silicon surface treatment on the electrical and photoelectric properties of nanostructured $\mathrm{MoO}_{\mathrm{x}} / n$-Si heterojunctions. The nanostructured heterojunctions $\mathrm{MoO}_{\mathrm{x}} / n-\mathrm{Si}$, were prepared by deposition of thin films of molybdenum oxide ( $n$-type conductivity) by reactive magnetron sputtering in the universal vacuum system Leybold Heraeus L560 on the nanostructured silicon substrates ( $n$-type conductivity), which were made by chemical etching with the assistance of silver nanoparticles. Dark and light volt-ampere $(I-V)$ characteristics of the heterojunctions under study were measured, the value of the potential barrier height, the values of the serial $R_{\mathrm{S}}$ and the shunt $R_{\mathrm{sh}}$ resistance at room temperature were determined. It was established that the silicon surface treatment does not affect the potential barrier height, but significantly affects the values of serial $R_{\mathrm{s}}$ and shunt $R_{\mathrm{sh}}$ resistance. The electrical and photoelectric properties of the obtained structures were investigated, the dominant mechanisms of current transfer through the heterostructures under forward bias are well described in the framework of emissionrecombination and tunneling models with the presence of interface states. The main mechanism for the charge carrier transport through heterojunctions with the reverse bias is the Frenkel-Pool emission. Investigation of photoelectric properties of heterojunctions $\mathrm{MoO}_{\mathrm{x}} / n$-Si was carried out at illumination by white light with intensity $P_{\mathrm{opt}}=80 \mathrm{~mW} / \mathrm{cm}^{2}$. It was established that the heterostructure No.5 $\mathrm{MoO}_{x} / n$-Si with grown nanowires and etched silver nanoparticles has a maximum open-circuit voltage $V_{\mathrm{oc}}=0.17 \mathrm{~V}$, short-circuit current density $I_{\mathrm{sc}}=10 \mathrm{~mA} / \mathrm{cm}^{2}$. The possibilities of using the obtained heterostructures as photodiodes were analyzed.
\end{abstract}

KEY WORDS: surface treatment, series resistance, current transfer mechanisms, molybdenum oxide, silicon.

In recent years the interest to the research of semiconductor heterojunctions created on the basis of thin films of transition metal oxides has considerably grown up. Molybdenum oxide $\left(\mathrm{MoO}_{\mathrm{x}}\right)$ has found practical application in electronics and in photovoltaic devices long ago due to high work function of electron and good physical properties: it has a high transmission factor in the visible part of the spectrum [1], a low electrical resistivity [2], the band gap width $\mathrm{E}_{\mathrm{g}}>3 \mathrm{eV}[3,4]$. In our previous work [5] we showed the possibility to form planar photosensitive heterostructures based on silicon and molybdenum oxide. It is known that the expansion of the scope of such heterostructures application is possible by creating nanostructured surfaces of the base material.

The silicon-based nanostructures are attribute components of the up-to-date instrument engineering in the field of electronics, optoelectronics, chemical sensors, as well as for the conversion and accumulation of solar energy. The silicon surface, which is modified by arrays of nanowires, has a low reflection coefficient and a large active area, what allows its successful practical application [6]. Judging by the aforesaid, the creation and study of nanostructured $\mathrm{MoO}_{\mathrm{x}} / \mathrm{Si}$ heterojunctions is of considerable scientific and practical interest.

The objective of the work is to study the effect of silicon surface treatment on the electrical and photoelectric properties of nanostructured $\mathrm{MoO}_{\mathrm{x}} / \mathrm{n}-\mathrm{Si}$ heterojunctions.

\section{EXPERIMENTAL PART}

To grow nanowires the monocrystalline silicon of n-type conductance with surface orientation (100) and thickness of $330 \mu \mathrm{m}$ was used. The resistivity and concentration of the crystals charge carriers at the temperature $(295 \mathrm{~K})$ made: $\rho=6 \mathrm{Ohm} \cdot \mathrm{cm}$ and $n=7.4 \cdot 10^{14} \mathrm{~cm}^{-3}$, respectively. The depth of the burial level - Fermi for the base material $\left(E_{c}-E_{F}=0.27 \mathrm{eV}\right)$ was determined from the expression for the concentration of equilibrium electrons: $n=2\left(2 \pi m_{n} k T / h^{2}\right)^{3 / 2} \exp \left(-\left(E_{C}-E_{F}\right) / k T\right)$.

To remove the native oxide and to purify the surface from the contaminants the silicon plates were chemically etched in 5\% solution of hydrofluoric acid (HF) in bi-distilled water for 5 minutes. At the start of the nanowires growing the silicon substrates were washed in an ultrasonic bath in bi-distilled water and in acetone, after washing the substrates were etched in a solution of sulfuric acid and 30\% of hydrogen peroxide $\left(\mathrm{H}_{2} \mathrm{O}_{2}\right)$ in the appropriate ratio (3:1) to remove the organic contaminants. After purification our samples were immersed in pre-prepared aqueous solutions of $0.02 \mathrm{M} \mathrm{AgNO} 3$ and of $5 \mathrm{M} \mathrm{HF}$ in the ratio $(1: 1)$ for 5-10 seconds in order to deposit silver nanoparticles on the substrates [5-6].

After deposition of silver nanoparticles some part of the substrates were taken to create heterostructures, and the others for the next steps to create nanowires. The next step to create nanowires was etching of silicon substrates with silver nanoparticles in the solution of $5 \mathrm{M} \mathrm{HF}$ and $30 \% \mathrm{H}_{2} \mathrm{O}_{2}$ in the ratio (10:1). Also, after creating nanowires on the 
silicon substrate with intercalated silver nanoparticles, some part of the substrates was taken to create heterostructures. The final procedure was etching silver nanoparticles from the substrate itself using nitric acid.

Thin $\mathrm{MoO}_{\mathrm{x}}$ films were deposited on the surface of nanostructured monocrystalline $\mathrm{Si}$ (size $5 \times 5 \times 0.36 \mathrm{~mm}$ ) with orientation (100) in the universal vacuum device Leybold Heraeus L560 by reactive magnetron sputtering of a pure molybdenum target in the atmosphere of argon and oxygen mixture under the forward-current voltage. Before starting the spraying process the vacuum chamber was pumped out to the residual pressure of $5 \cdot 10^{-3} \mathrm{~Pa}$. The partial pressures of argon and oxygen were $0.24 \mathrm{~Pa}$ and $0.034 \mathrm{~Pa}$, respectively, at the constant magnetron power of $30 \mathrm{~W}$. In the course of spraying process the substrate temperature is maintained at $573 \mathrm{~K}$. The spraying process lasted for 3 minutes.

After finishing the process of deposition of the $\mathrm{MoO}_{\mathrm{x}}$ thin films the vacuum chamber was gradually cooled to room temperature and then was opened to replace the molybdenum target with ITO target $\left(\mathrm{In}_{2} \mathrm{O}_{3}-\mathrm{SnO}_{2} 90: 10\right.$ by mass). The deposition of ITO thin $0.15 \mu \mathrm{m}$-thick films, which were used as an antireflection coating, was carried out by the method of magnetron sputtering of the ITO target in the Argon atmosphere under the direct-current voltage.

During the process of deposition the argon pressure in the vacuum chamber was $\sim 0.4 \mathrm{~Pa}$. The installed power of the magnetron was $\sim 30 \mathrm{~W}$. The deposition process lasted for $\sim 5 \mathrm{~min}$. at the substrate temperature of $\sim 420 \mathrm{~K}$. To provide the frontal electric contact with the thin $\mathrm{MoO}_{\mathrm{x}}$ film the conducting paste was used. To avoid recombination on the rear side of silicon and to ensure a good set of photogenerated charge carriers, we used substrates that previously had rear contact with the built-in internal field. The contact was created by sputtering a layer of the intrinsic hydrogenated amorphous silicon (a-Si:H) with the thickness of $\sim 10 \mathrm{~nm}$ to passivate the substrate surface, the next layer of hydrogenated amorphous silicon $\mathrm{n}^{+}(\mathrm{a}-\mathrm{Si}: \mathrm{H})$ with the thickness of $\sim 20 \mathrm{~nm}$, which was heavily doped with phosphorus, to create isotype junction with the barrier height of $\sim 0.1 \mathrm{eV}$ on the rear side of $\mathrm{Si}$, and the last layer of $\mathrm{Al}$ was deposited by thermal evaporation (the block diagram is shown in the inset of Fig. 1).

\section{RESULTS AND DISCUSSION \\ ELECTRICAL PROPERTIES OF NANOSTRUCTURED HETEROJUNCTIONS $\mathrm{MoO}_{\mathrm{x}} / \mathbf{n}-\mathrm{Si}$}

The $\mathrm{MoO}_{\mathrm{x}} / \mathrm{n}$-Si heterostructures were prepared using the method of reactive magnetron sputtering of molybdenum oxide thin films on the single-crystal n-Si substrates with different surface treatment (Table 1).

Conditions for $\mathrm{MoO}_{\mathrm{x}} / \mathrm{n}-\mathrm{Si}$ heterostructures preparation

Table 1.

\begin{tabular}{|c|c|}
\hline $\begin{array}{l}\text { Sample } \\
\text { No. } 1\end{array}$ & $\begin{array}{l}\text { The } \mathrm{MoO}_{x} / \mathrm{n} \text {-Si heterostructure was prepared without chemical } \\
\text { treatment of the substrates. }\end{array}$ \\
\hline $\begin{array}{l}\text { Sample } \\
\text { No. } 2\end{array}$ & $\begin{array}{l}\text { The } \mathrm{MoO}_{\mathrm{x}} / \mathrm{n}-\mathrm{Si} \text { heterostructure: } \mathrm{Si} \text { substrates were etched in } 5 \% \\
\text { aqueous solution of } \mathrm{HF} \text {. }\end{array}$ \\
\hline $\begin{array}{l}\text { Sample } \\
\text { No. } 3\end{array}$ & $\begin{array}{l}\text { The } \mathrm{MoO}_{\mathrm{x}} / \mathrm{n}-\mathrm{Si} \text { heterostructure: silver nanoparticles were deposited on } \\
\text { Si substrates. }\end{array}$ \\
\hline $\begin{array}{l}\text { Sample } \\
\text { No. } 4\end{array}$ & $\begin{array}{l}\text { The MoOx/n-Si heterostructure: nanowires with intercalated silver } \\
\text { nanoparticles were grown on } \mathrm{Si} \text { substrates. }\end{array}$ \\
\hline $\begin{array}{l}\text { Sample } \\
\text { No. } 5\end{array}$ & $\begin{array}{l}\text { The } \mathrm{MoO}_{\mathrm{x}} / \mathrm{n} \text {-Si heterostructure: nanowires were grown on Si substrates } \\
\text { and silver nanoparticles were etched. }\end{array}$ \\
\hline
\end{tabular}

Fig. 1 shows the volt-ampere characteristics and dependences of the differential resistance [7] on the applied bias for the $\mathrm{MoO}_{\mathrm{x}} / \mathrm{n}-\mathrm{Si}$ heterojunctions with different treatment of Si surface, listed in Table 1.

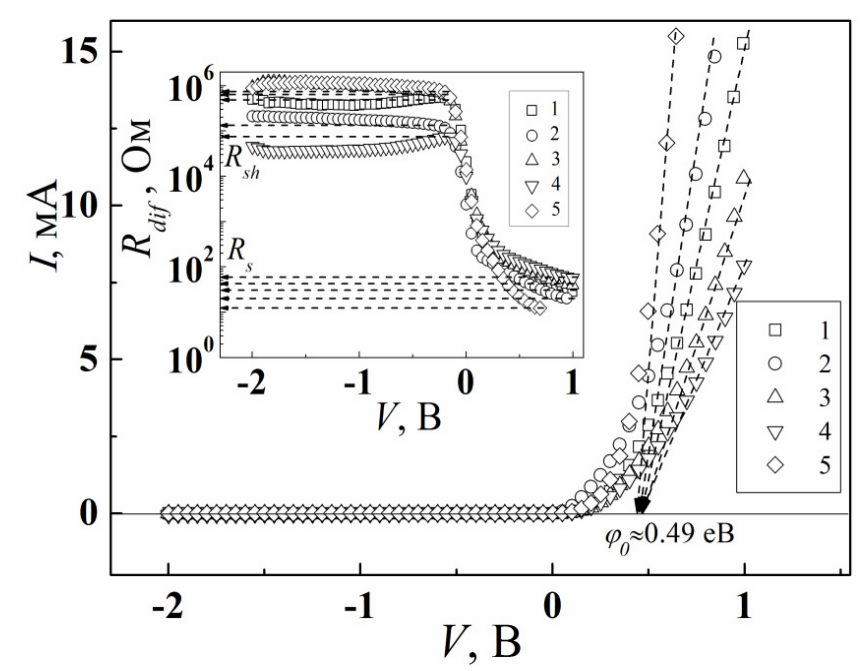

Fig. 1. I- $V$ characteristics of $\mathrm{MoO}_{\mathrm{x}} / \mathrm{n}-\mathrm{Si}$ heterojunctions.

The inset shows the dependence of the differential resistance of $\mathrm{MoO}_{\mathrm{x}} / \mathrm{n}-\mathrm{Si}$ heterojunctions on the applied voltage (at room temperature) 
Table 2 presents the major parameters of heterojunctions subject to the volt-ampere characteristics: heterojunction rectification factor $k$, the value of the potential barrier height $\varphi_{0}$, and the value of the series and shunt resistance of heterojunctions.

Table 2.

Parameters of $\mathrm{MoO}_{\mathrm{x}} / \mathrm{n}$-Si heterojunctions

\begin{tabular}{|c|c|c|c|c|}
\hline Sample & $k$ at $V=0,7 \mathrm{~V}$ & $\varphi_{0}, \mathrm{eV}$ & $R_{\mathrm{s}}, \Omega$ & $R_{\text {sh }}, \Omega$ \\
\hline 1 & $2.3 \times 10^{3}$ & 0.49 & 30 & $6.1 \times 10^{5}$ \\
\hline 2 & $5.2 \times 10^{2}$ & 0.49 & 20 & $1.3 \times 10^{5}$ \\
\hline 3 & $1.3 \times 10^{3}$ & 0.49 & 42 & $6.7 \times 10^{5}$ \\
\hline 4 & $2.6 \times 10^{2}$ & 0.49 & 59 & $7.4 \times 10^{4}$ \\
\hline 5 & $6.3 \times 10^{3}$ & 0.49 & 13 & $7.5 \times 10^{5}$ \\
\hline
\end{tabular}

As Fig. 1 and Table 2 show, that the Si surface treatment does not affect the height of the potential barrier since its value depends on the difference in the work function of the heterojunction components, and its value can be affected by the electric charge localized on the surface energy states. However, the surface treatment significantly affects the value of the series resistance $R_{s}$. Table 2 shows that the substrate surface treatment in HF (sample 2) causes a decrease in the series resistance due to the removal of the native oxide $\left(\mathrm{SiO}_{2}\right)$ from the substrate surface, but to determine more precisely the reasons for the series resistance growth an additional research is required. The lowest value of the series resistance for sample No. 5 is stipulated by an increase in the active area of the developed heterojunction surface and by a decrease in the effective length of the base material [8], while the highest values of the rectification factor and shunt resistance indicate that heterostructure No. 5 is the best among all the above-listed ones.

\section{MECHANISMS OF CURRENT TRANSFER IN THE NANOSTRUCTURED MoO $\mathrm{O}_{\mathbf{x}} / \mathbf{n}-\mathrm{Si}$ HETEROJUNCTIONS \\ Forward biases}

The analysis of the forward branches of $I-V$ characteristics of $\mathrm{MoO}_{\mathrm{x}} / \mathrm{n}-\mathrm{Si}$ structures built in a semi-log scale (Fig. 2), with the influence of series and shunt resistances taken into account, showed that the dependence $\ln \left[I-\left(V-I R_{s}\right) / R_{s h}\right]=f\left(V-I R_{s}\right)$ comprises two straight portions, what indicates to the exponential dependence of the current on the voltage and to the presence of two dominant mechanisms of charge transfer in the voltage range under study. The values of the nonideality factor according to $\Delta \ln \left[I-\left(V-I R_{s}\right) / R_{s h}\right] / \Delta\left(V-I R_{s}\right)=e / n k T$, where $n$ is the nonideality factor, determined for the both voltage portions are given in Table 3.

A small value of the potential barrier height $\varphi_{0}=0.49 \mathrm{eV}$, as a rule, leads to the flow of the over-barrier current. In the voltage range $(3 k T / e<V<0.2 V)$ the dependence $I(V)$ is well described by the expression for the emissionrecombination mechanism of current transfer with the influence of the series and shunt resistances taken into account (direct recombination of charge carriers through the energy states on the interface, which is determined by the potential barrier height) $[9,5]$ :

$$
I=I_{s}\left[\exp \left(\frac{q\left(V-I R_{s}(T)\right)}{n k T}\right)-1\right]+\frac{V-I R_{s}}{R_{s h}},
$$

where

$$
I_{s}=B_{0} \exp \left(-\frac{\varphi_{0}(T)}{n k T}\right),
$$

$B_{0}$ is the coefficient that depends weakly on the temperature, the coefficient $n$, as a rule, varies from 1 to 2 , what correlates well with experimentally obtained values (Table 3 ).

$\mathrm{MoO}_{\mathrm{x}} / \mathrm{n}$-Si heterojunction parameters

Table 3.

\section{MoOr/ni heterojunction parameters}

\begin{tabular}{|c|c|c|c|}
\hline Sample & $n$ & $n$ & \\
& $(3 k T / e<\mathrm{V}<0.2 \mathrm{~V})$ & $(0.2<V<0.4 V)$ & $a, B^{-1}$ \\
\hline 1 & 1.58 & 3.64 & 10.76 \\
\hline 2 & 1.80 & 5.49 & 7.68 \\
\hline 3 & 1.66 & 3.64 & 10.76 \\
\hline 4 & 1.65 & 3.77 & 10.40 \\
\hline 5 & 1.50 & 2.97 & 13.20 \\
\hline
\end{tabular}

When the emission-recombination mechanism is dominant, it is considered that the recombination centers are uniformly distributed by energy and are concentrated in a narrow region near the interface.

Taking the logarithm of expression (1) we obtain: 


$$
\ln \left(I-\frac{V-I R_{s}(T)}{R_{s h}}\right)=I_{s}+\frac{q\left(V-I R_{s}(T)\right)}{n k T}
$$

From the last expression it is evident that the dependences $\ln \left(I-\left[V-I R_{s}\right] / R_{s h}\right)=\mathrm{f}\left(V-I R_{s}\right)$ should be approximated by straight lines with a slope, what is really observed (Fig. 2).

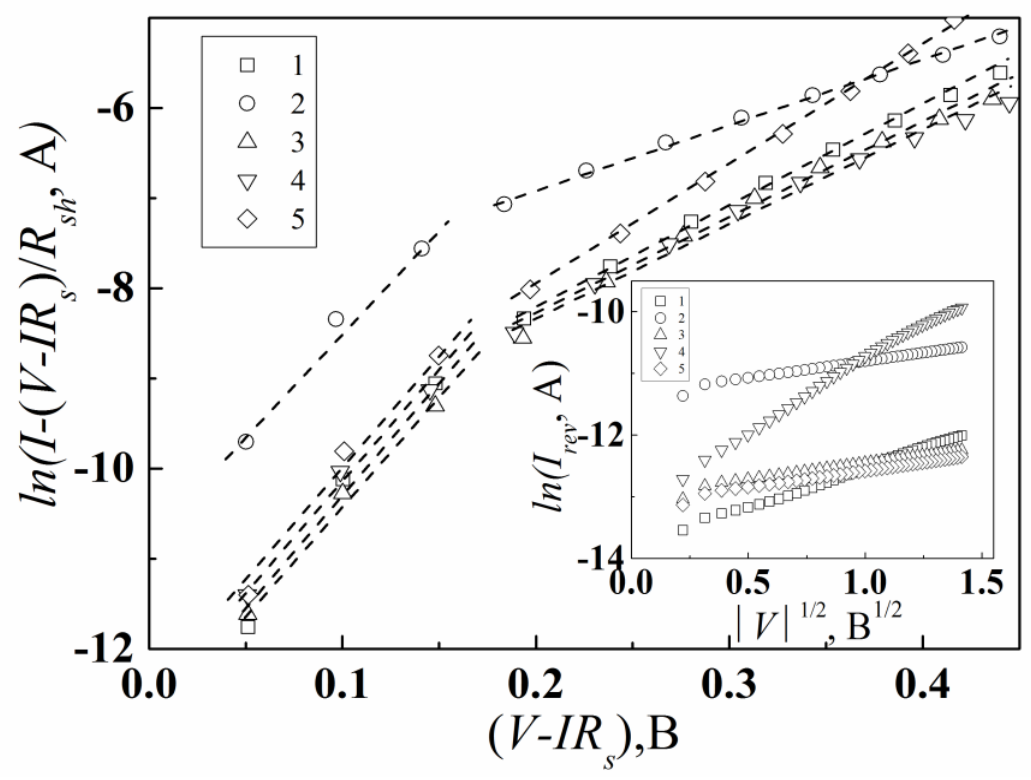

Fig. 2. Forward branches of $I-V$ characteristics of $\mathrm{MoO}_{\mathrm{x}} / \mathrm{n}-\mathrm{Si}$ heterojunctions in a semi-log scale, with the influence of series and shunt resistances taken into account

The inset shows the dependences described by the Frenkel-Poole emission through $\mathrm{MoO}_{\mathrm{x}} / \mathrm{n}$-Si heterojunctions at reverse bias.

In the voltage range $0.2<V<0.4 \mathrm{~V}$ a small constant slope (a large value of the nonideality factor $n>2$ ) of the experimental dependences $\ln (I)=\mathrm{f}(V)$ at different temperatures can be considered as an evidence of the tunneling nature of the current transfer mechanism [10]. Straight portions of $I-V$ characteristics with identical slopes occur at sufficiently large biases, where the space charge region is sufficiently thin for direct tunnel effect, which is described by Newman formula for the tunneling mechanism of current transfer with the effect of series resistance taken into account $[9,10]$ :

$$
I=I_{t}^{0} \exp (\beta T) \cdot \exp \left[\alpha\left(V-I R_{s}\right)\right]
$$

$I_{t}^{0}, \alpha, \beta$ are constants. The experimental value of $\alpha$ was determined from the dependence $\ln (I)=\mathrm{f}\left(V-I R_{s}\right)$ and is shown in Table 3 .

\section{Reverse biases}

The dependence $\mathrm{I}_{\mathrm{rev}}(V)$ is well described in the framework of the model based on the Frenkel-Poole emission. The essence of the corresponding processes is the thermal excitation of charge carriers, captured by surface traps, facilitated by electric field [11].

The dependence of the electric field strength on the reverse voltage $E(V)$ in the space charge region of the asymmetric heterojunction was estimated by the formula taken from [5].

The dependence of the reverse current on the voltage $(0.12<|V|<2 \mathrm{~V})$, plotted in coordinates $\ln \left(I_{\text {rev }}\right)=f|V|^{1 / 2}$ is shown in the inset of Fig. 2 and is well approximated by straight lines, what confirms the validity of the proposed mechanism of the current transfer. Curve 4 (for the sample with the intercalated silver nanoparticles) deviates from the others, what is due to formation of silver oxide or silver-containing compounds with dielectric properties in this heterostructure, and as a result some additional traps or recombination centers are formed that affect the current flow.

\section{PHOTOELECTRIC PROPERTIES OF NANOSTRUCTURED MoOx/n-Si HETEROJUNCTIONS}

Figure 3 presents the dark and light $I-V$ characteristics of $\mathrm{MoO}_{\mathrm{x}} / \mathrm{n}-\mathrm{Si}$ heterostructures.

As Fig. 3 shows, at illumination with white light with the intensity of $80 \mathrm{~mW} / \mathrm{cm}^{2}$ the forward and reverse current $I_{\text {light }}$ increases as compared to their values in the dark zone $I_{\text {dark. }}$. The heterostructure parameters determined from the dependence $I=f(V)$ had the following values (Table 4). 


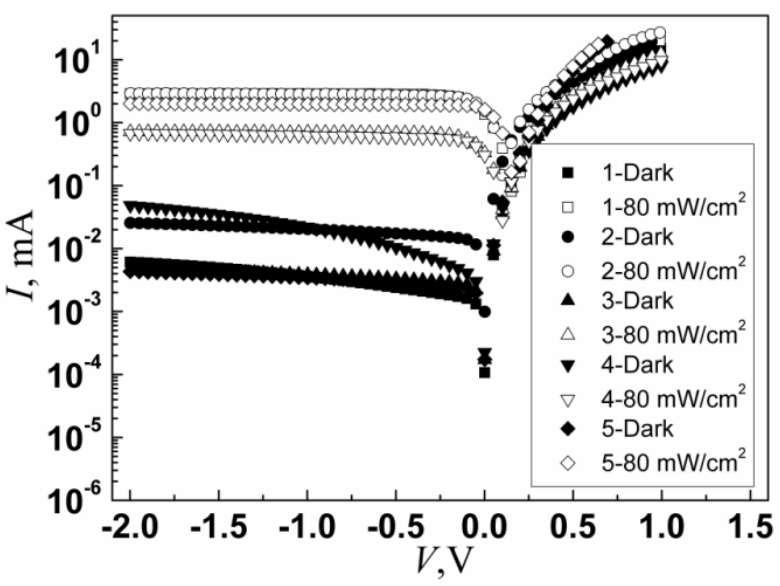

Fig.3. Dark and light $I-V$ characteristics of $\mathrm{MoO}_{x} / \mathrm{n}-\mathrm{Si}$ heterojunctions in a semi-log scale

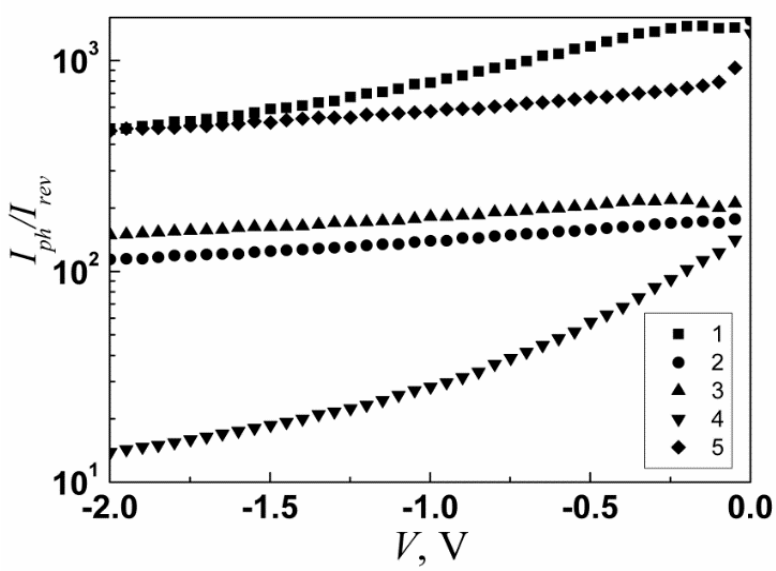

Fig.4. The $I_{p h} / I_{r e v}=\mathrm{f}(\mathrm{V})$ dependencies of $\mathrm{MoO}_{\mathrm{x}} / \mathrm{n}-\mathrm{Si}$ heterojunctions in a semi-log scale

Table 4.

Photoelectric parameters of $\mathrm{MoO}_{\mathrm{x}} / \mathrm{n}$-Si heterojunctions

\begin{tabular}{|c|c|c|}
\hline Sample & $V_{\text {oc }}, \mathrm{V}$ & $I_{\text {sc }}, \mathrm{mA} / \mathrm{cm}^{2}$ \\
\hline 1 & 0,167 & 8,56 \\
\hline 2 & 0,113 & 9,56 \\
\hline 3 & 0,117 & 2 \\
\hline 4 & 0,11 & 1,87 \\
\hline 5 & 0,17 & 10 \\
\hline
\end{tabular}

A large ratio between the photocurrent and the dark reverse current $I_{p h} / I_{r e v}$ shows that the heterostructures under study can be used as photodiodes (Fig. 4). At the same time, Fig. 4 shows that for sample 4 (with intercalated silver nanoparticles) the photoelectric parameters are the lowest. Due to the negative effect of the intercalated silver nanoparticles on the current transfer mechanisms, as well as the barrier and photoelectric parameters of the obtained structures, these silver nanoparticles are to be etched in nitric acid when growing nanowires on silicon by the above described method.

Table 4 shows that heterostructure No. 5 has the highest photoelectric parameters among the heterostructures under study, and after their refinement by introducing intermediate layers and high-quality passivation of dangling bonds in silicon they can be used as solar cells.

\section{CONCLUSION}

The effect of surface treatment of $\mathrm{Si}$ substrates on the electrical and photoelectric properties of $\mathrm{MoO} / \mathrm{n}-\mathrm{Si}$ heterostructures was studied.

Photosensitive $\mathrm{MoO}_{\mathrm{x}} / \mathrm{n}$-Si heterojunctions were obtained by the method of reactive magnetron sputtering.

The $I-V$ characteristics were measured. The electrical properties and barrier parameters of the obtained heterostructures were investigated.

The studies have shown that the mechanisms of current transfer through the heterostructures under forward bias are well described in the framework of emission-recombination and tunnel models with the presence of interface states. The basic mechanism for the charge carrier transfer through the heterojunctions at reverse bias is Frenkel-Poole emission.

The authors have found that the heterostructures are photosensitive and can be used as photodiodes.

\section{ORCID IDs}

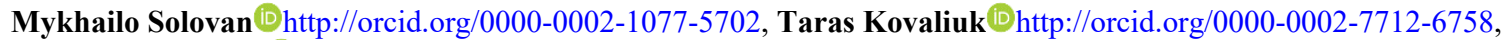
Pavlo Maryanchuk $@$ https://orcid.org/0000-0002-5523-4280

\section{REFERENCES}

[1]. S. Subbarayudu, V. Madhavi and S. Uthanna, Adv. Mat. Lett. 4(8), 637 (2013), doi: 10.5185/amlett.2012.11466.

[2]. L.D. López-Carreño, A. Pardo, M. Zuluaga, O.L. Cortés-Bracho, J. Torres, and J.E. Alfonso, Phys. Stat. Sol. (c). 4, 4064 (2007), doi: 10.1002/pssc.200775931.

[3]. A.L. Fahrenbruch and R.H. Bube Fundamentals of Solar Cells. Photovoltaic Solar Energy Conversion (Academic, New York, 1983).

[4]. V.V. Brus, M.I. Ilashchuk, Z.D. Kovalyuk, P.D. Maryanchuk and K.S. Ulyanytskiy, Semicond. Sci. Technol. 26, 125006 (2011). 
[5]. M.M. Solovan, Journal of Nano- and Electronic Physics. 10(2), 02030 (2018).

[6]. M.M. Solovan, V.V. Brus, A.I. Mostovyi, P.D. Maryanchuk, I.G. Orletskyi, T.T. Kovaliuk and S.L. Abashin, Semiconductors. 51(4), 542 (2017).

[7]. L.A. Kosyachenko, X. Methew, V.V. Motushchuk and V.M. Sklyarchuk, Solar Energy. 80, 148 (2006).

[8]. H.P. Parkhomenko, M.M. Solovan and P.D. Maryanchuk, Journal of Nano- and Electronic Physics. 10(2), 02028 (2018).

[9]. B.L. Sharma and R.K. Purohit, Semiconductor heterojunctions, Vol. 5. (Pergamon Press, New York, 2015), p. 224.

[10]. A. Fahrenbruch and R. Byub, Solar cells (theory and experiment), (Energoatomizdat, Moscow, 1987), p. 278.

[11]. S.M. Sze and K. Kwok, Physics of Semiconductor Devices, 3rd ed. (Wiley, New Jersey, 2007), p. 815.

[12]. V.V. Brus, M.I. Ilashchuk, V.V. Khomyak, Z.D. Kovalyuk, P.D. Maryanchuk and K.S. Ulyanytsky, Semiconductors, 9, 1152 (2012).

\section{ВПЛИВ ОБРОБКИ ПОВЕРХНІ КРЕМНІЮ НА ЕЛЕКТРИЧНІ І ФОТОЕЛЕКТРИЧНІ ВЛАСТИВОСТІ НАНОСТРУКТУРОВАНИХ ГЕТЕРОПЕРЕХОДІВ МоOx/n-Si}

М.М. Солован, Т.Т. Ковалюк, П.Д. Мар'янчук

Чернівецький національний університет імені Юрія Федьковича вул. Кочюбинського 2, 58012 Чернівиі, Україна

У роботі представлено результати досліджень впливу обробки поверхні кремнію на електричні та фотоелектричні властивості наноструктурованих гетеропереходів $\mathrm{MoO}_{\mathrm{x}} / n-\mathrm{Si}$. Наноструктуровані гетеропереходи $\mathrm{MoO}_{\mathrm{x}} / \mathrm{n}-\mathrm{Si}$, створено шляхом нанесення тонких плівок оксиду молібдену ( $n$-типу провідності) методом реактивного магнетронного розпилення в універсальній вакуумній установці Leybold Heraeus L560 на наноструктуровані підкладки кремнію ( $n$-типу провідності), які виготовляли шляхом хімічного травлення за участю наночасток срібла. Виміряні темнові та світлові вольт-амперні характеристики (BAX) досліджуваних гетеропереходів, визначено значення висоти потенціального бар'єру, значення послідовного $R_{\mathrm{s}}$ i шунтуючого $R_{\mathrm{sh}}$ опорів при кімнатній температурі. Встановлено, що обробка поверхні кремнію не впливає на висоту потенціального бар'єру, але суттєво впливає на величину послідовного $R_{\mathrm{s}}$ та шунтуючого $R$ sh опорів. Досліджено електричні і фотоелектричні властивості отриманих структур, домінуючі механізми струмопереносу через гетероструктури при прямому зміщенні добре описуються в рамках емісійно - рекомбінаційної та тунельної моделей за участю поверхневих станів. Основним механізмом переносу носіїв заряду через гетеропереходи при зворотному зміщенні є емісія ФренкеляПула. Дослідження фотоелектричних властивостей гетеропереходів $\mathrm{MoO}_{\mathrm{x}} / n-\mathrm{Si}$ проводили при опроміненні білим світлом інтенсивністю $P_{\mathrm{opt}}=80 \mathrm{mBT} / \mathrm{cm}^{2}$. Встановлено, що гетероструктура №5 $\mathrm{MoO}_{\mathrm{x}} / \mathrm{n}-\mathrm{Si} 3$ вирощеними нанодротами $\mathrm{i}$ витравленими наночастками срібла має максимальну напругу холостого ходу $V_{o c}=0,17$ В, густину струму короткого замикання $I_{s c}=10 \mathrm{~mA} / \mathrm{cm}^{2}$. Проаналізовано можливості застосування отриманих гетероструктур в якості фотодіодів.

КЛЮЧОВІ СЛОВА: обробка поверхні, послідовний опір, механізми струмопереносу, оксид молібдена, кремній.

\section{ВЛИЯНИЕ ОБРАБОТКИ ПОВЕРХНОСТИ КРЕМНИЯ НА ЭЛЕКТРИЧЕСКИЕ И ФОТОЭЛЕКТРИЧЕСКИЕ СВОЙСТВА НАНОСТРУКТУРИРОВАННЫХ ГЕТЕРОПЕРЕХОДОВ МоOх/n-Si}

\section{М.Н. Солован, Т.Т. Ковалюк, П.Д. Марьянчук}

Черновицкий национальный университет имени Юрия Федьковича

ул. Коиюбинского 2, 58012 Черновиь, Украина

В работе представлены результаты исследований влияния обработки поверхности кремния на электрические и фотоэлектрические свойства наноструктурированных гетеропереходов $\mathrm{MoO}_{\mathrm{x}} / n-\mathrm{Si}$. Наноструктурированные гетеропереходы $\mathrm{MoO}_{x} / n-\mathrm{Si}$, созданы путем нанесения тонких пленок оксида молибдена ( $n$-типа проводимости) методом реактивного магнетронного распыления в универсальной вакуумной установке Leybold Heraeus L560 на наноструктурированные подложки кремния (n-типа проводимости), которые изготавливали путем химического травления с участием наночастиц серебра. Измерены темновые и светловые вольт-амперные характеристики (ВАХ) изучаемых гетеропереходов, определено значение высоты потенциального барьера, значение последовательного $R_{\mathrm{s}}$ и шунтирующего $R_{\mathrm{sh}}$ сопротивлений при комнатной температуре. Установлено, что обработка поверхности кремния не влияет на высоту потенциального барьера, но существенно влияет на величину последовательного $R_{\mathrm{s}}$ и шунтирующего $R_{\mathrm{sh}}$ сопротивлений. Исследовано электрические и фотоэлектрические свойства полученных структур, доминирующие механизмы токопереноса через гетероструктуры при прямом смещении хорошо описываются в рамках эмиссионно-рекомбинационной и туннельной моделей с участием поверхностных состояний. Доминирующим механизмом переноса носителей заряда через гетеропереходы при обратном смещении является эмиссия Френкеля-Пула. Исследование фотоэлектрических свойств гетеропереходов $\mathrm{MoO} / n-\mathrm{Si}$ проводили при облучении белым светом интенсивностью $P_{\text {орt }}=80 \mathrm{mBт} / \mathrm{cm}^{2}$. Установлено, что гетероструктура №5 $\mathrm{MoO}_{\mathrm{x}} / n-\mathrm{Si}$ с выращенными нанопроводами и вытравленными наночастицами серебра имеет максимальное напряжение холостого хода $V_{\mathrm{oc}}=0.17 \mathrm{~B}$, плотность тока короткого замыкания $I_{\mathrm{sc}}=10 \mathrm{MA} / \mathrm{cm}^{2}$. Проанализированы возможности применения полученных гетероструктур в качестве фотодиодов.

КЛЮЧЕВЫЕ СЛОВА: обработка поверхности, последовательное сопротивление, механизмы токопереноса, оксид молибдена, кремний. 